\title{
Feral Burros and Woody Plants: An Ecological Assessment of Risks
}

\author{
By Charles D. Bonham and Karla A. Brown
}

There is a concern that feral burros browsing certain shrubs in the Mojave Desert may be placing these species at risk. Here, we assess the ecological risk of that browsing-where risk is defined as the likelihood of a shrub being damaged by browsing. No risk is present unless the burro causes one or more adverse effects on the plant by browsing it. In addition, this browsing has to occur over a sufficient time interval and with enough intensity so that adverse effects to the shrub can be observed.

We examined the qualitative effects of burro browsing on three desert shrubs and assessed risks to littleleaf palo verde, white bursage, and catclaw acacia in the Lake Mead Recreational Area, National Park Service, located near Boulder City, Nevada. The species potential trends, recovery rates, and population dynamics resulting from the removal of the non-native burros were also addressed.

The study area is in Mojave Desert and vegetation types are often dominated by one of the three study shrub species. Annual precipitation of approximately 6 inches occurs primarily in the summer and winter. Average annual high temperatures are $102^{\circ} \mathrm{F}$, with maximum temperatures occurring in July and August while the average low temperature is $38^{\circ} \mathrm{F}$ in January and February. The study species are well adapted to the extreme environments and take up water and nutrients as they are available to continue growth and reproduction.

\section{Recovery Dynamics Of Desert Shrubs}

Recovery for heavily browsed or grazed desert shrubs require long periods of time (perhaps greater than 100 years) and the three shrub species will likely respond differently depending on intensity of browsing. Studies of similar vegetation systems have reported that plant species, other than shrubs, did not change much over a long period of time (greater than 50 years), although numbers of individuals of species and kinds of plant species varied greatly over that time.

Hanley and Brady showed that feral burros browsing on shrubs did not cause other plants to increase or to invade desert shrub communities similar to those of this study. Therefore, trends in the three shrub species that may be expected as feral burros and livestock are re- moved or reduced in numbers will probably include an increase in shrub density, but will show minimal changes in plant community composition.

\section{Climatic Variables and Plant Responses}

Temperature and moisture extremes are found in the study area and affect prediction of shrub risks and responses to browsing, and will continue to do so in the coming decades. Shrubs will generally incur heavier browsing pressure from the burros and other mammalian herbivores during periods of extended drought. Whether permanent damage will occur to a specific shrub species will be a function of the herbivore population size as noted by Turner, because desert shrubs have a large capacity for reproduction when an unusually wet year occurs.

Long-term changes in the regional climate of the desert-on-sand province areas may further increase risks from over-browsing to all three of these shrub species. Turner stated that the last half of the $20^{\text {th }}$ Century will be the driest period since 1700; if current climatic trends continue it will be more difficult for these shrubs to rebound from periods of intensive browsing.

\section{Risks To The Three Species}

An overview on species morphology, species associations, life history traits, site-specific distribution, and general palatability to grazers is presented for each shrub species. This information was synthesized and used to define ecological risk to the individual species when over browsed by burros.

\section{Little-leaf Palo Verde}

This species is a common desert tree and has a northern extension into Lake Mead National Recreation Area. Palo verde is a drought-deciduous species and looses its leaves in mid-May and develops leguminous fruit; it generally occurs in the hottest, driest areas. It's presence may be attributed to a rooting system that reaches deep, available, soil water. Average plant canopy height is 10 to 12 feet. The shrub is a long-lived species $(>100$ years), has few mature individuals, and rarely has young plants establishing in the area. 
Palo verde saplings occur under cheesebush canopies more often than under adult palo verde and creosote bush canopies. Observations also showed that grazing pressure from hares and small rodents limited little-leaf palo verde seedlings to areas beneath adult palo verde, cheesebush, and creosote bush canopies despite potential competitive effects.

The legume fruit produced by the shrub is not eaten by animals until other food is gone. The shrub did not appear to be preferred by burros in its green leafy stage, but yellowed twigs and branches up to 1 inch in diameter were preferred.

Impacts to Little-leaf palo verde: The successful establishment of palo verde seedlings may rely upon their association with protective canopies provided by white bursage. White bursage appears to be an important species in this respect; i.e., colonizing bare areas and serving as a "nurse-plant" for the establishment of other species.

Paloverde is also a major component of the feral burro diet and is threatened by this potentially dominant herbivore in parts of the study area. Use of this plant by burros throughout the year with particularly heavy utilization during the summer months has been documented. But, the risks for potential over-browsing of adult plants are still continuous throughout the year and risks become particularly important during bud formation and leaf development. Yet, because burros prefer older yellowed leaves and stems, it does not seem likely that this plant will be more at risk from browsing pressures during germination and seedling development stages. The strong associations of palo verde seedlings, with the protection of white bursage canopy, will be a more important determinant of the risks of browsing on palo verde juveniles than will the season of browsing.

At moderate browsing levels, risks to palo verde should be low. On the other hand, as browsing intensity increases above carrying capacity, so will the amount of recovery time needed. The risks for permanent or longterm negative impacts on the species will also increase.

\section{Catclaw Acacia}

This species is found throughout the study area, has a wide range of sizes and shapes, but the larger individuals are found on benches while smaller plants are found in washes. Catclaw acacia is a co-dominant with cheesebush in some areas. The shrub is a winter-deciduous, short-lived shrub (life span of $<100 \mathrm{yr}$ ) that forms dense thickets, has numerous curved thorns on the stem, and bears yellow flowers from May to October. Fruits are 26 inches long in flat, pea-like brown pods. Catclaw can reach heights of 5-6 feet in height in the study area and may be a nitrogen fixer in soil.
Higher branches on the shrub are browsed by burros as evidenced by stripped bark and recurved branches. Burros have been observed to browse the plant more heavily from October to January and the plant contributed approximately $10 \%$ to the diet.

Impacts to Catclaw acacia: In the study area, catclaw acacia forms codominant vegetation types with cheesebush, and is distributed widely on benches and washes. This wide distribution may also account for the consistent low-level grazing pressure observed for this species. Woodward and Ohmart found catclaw acacia to be most heavily browsed by burros during October to

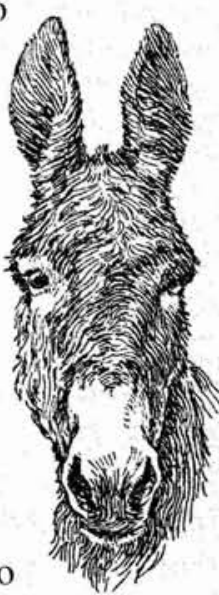
January when this shrub comprised up to $10 \%$

of the diet. This browse was also found to be used at low levels throughout the remainder of the year.

Because catclaw acacia is a long-lived drought resistant perennial like little-leaf palo verde, risks associated with browsing pressure on the species could increase significantly during periods of drought when annuals are scarce and browsers are forced to feed mostly on shrubs. The importance of this species as a nitrogen-fixer may also play an important role in nutrient cycling in this vegetation system. Therefore, risks to catclaw acacia could be passed on to other plant species that benefit from this characteristic.

\section{White Bursage}

This drought-deciduous shrub has a dense growth form with a canopy ranging from 1.5 to 3 feet in diameter. It has very small flowers that appear in early spring and later produces spiney, bur-like fruits 0.2 to 0.3 inches in diameter. In the study area, white bursage is often found on upland areas in association with creosote bush. Bursage is also found in major washes with little-leaf palo verde and creosote bush.

McAuliffe found that bursage provided little-leaf palo verde saplings with protection from grazing when the saplings were rooted beneath low-growing white bursage plants. Hanley and Brady reported that both burro and hare diets contained white bursage and studies by Woodward and Ohmart showed that burros browse this species heavily during December and January, when it makes up about $15 \%$ of the diet.

Impacts to White bursage: White bursage has a key role in the dynamics of desert and semiarid ecosystems of the Lake Mead National Recreation Area. As noted above, white bursage can be a colonizer for creosote bush and other species, and as a "nurse plant". It's dense canopy provides a cooler, more moist microclimate for 
the development of little-leaf palo verde or creosote bush seedlings. Therefore, the degree and severity to which white bursage is browsed also could impact the recovery dynamics of associated species. At the present, there is no information to indicate that this shrub species is any more susceptible to drought than the other two shrub species.

Hanley and Brady found that over-browsing by burros decreased canopy cover of white bursage even more in washes. It is reasonable to assume that large reductions in plant cover from burro browsing, indicate that white bursage is an effective monitor of the overall extent of browsing pressure from burros; not just impacts on bursage alone. Lastly, this species may be particularly at risk from over-browsing in the fall when leaves are maturing.

\section{Potential Impacts From Grazing}

Shrub species abundances and distributions in desert ecosystems can be changed by domestic livestock grazing and by bighorn sheep and feral burro browsing. Shrub responses to grazing/browsing depends on their palatability to grazing/browsing animals, on climatic conditions, and on individual shrub species morphological and life history traits.

For example, one of the well known principles used to manage rangeland grazing involves season and intensity of grazing which affect development of new leaves and flowers; these responses in turn determine the impacts and ecological risks of grazing the species. Over-browsing, in particular, affects the ability of a plant to compete with ungrazed species for limited water and nutrients in desert environments.

Individual plant attributes determine the amount of risk that plants incur from browsing or grazing and that this risk differs according to season and intensity of grazing. For example, in the three vegetation types: desert bajadas, major washes, and Colorado River riparian habitat, feral burros spent the majority of winter months on the bajadas.

During the spring, they move into washes and by summer they remain along the riparian corridor in the shade of the palo verde and saltcedar. These foraging patterns are reflected in their diets which are dominated by white bursage, catclaw acacia, and palo verde in the winter, desert Indian wheat in the spring months, and paloverde and mesquite during the summer. Therefore, the most important burro forages, such as white bursage, will be the most stressed and at the highest risk during time of drought when annuals become scarce or when overbrowsing occurs.

Chambers and Norton found that individual shrub species responses to the effects of both grazing and drought were more predictable from life cycle, and growth and maintenance than from past effects of browsing. These researchers also showed that negative effects from browsing during below-average precipitation years also occurred primarily under heavy or spring browsing regimes.

The potential impacts to these species can be limited by preventing excessive browsing and controlling populations of the feral burros to within the carrying capacity of the vegetation type. It is particularly important to avoid overstocking the area during the time young buds and flowers are developing which is during early summer.

Table 1 provides a summary of individual characteristics of the three shrub species and presents an evaluation of their risks from browsing pressures. It seems reason-

\begin{tabular}{|c|c|c|c|}
\hline Species & Littleleaf palo verde & Catclaw acacia & White bursage \\
\hline Morphology & - canopy height: $3-4 \mathrm{~m}$ & $\begin{array}{l}\text { - shrub canopy height: } 1.5-2.0 \mathrm{~m} \text {; } \\
\text { - nitrogen-fixer; }\end{array}$ & $\begin{array}{l}\text { - shrub canopy diametr: } \\
50 \text { - } 100 \mathrm{~cm} \text {; } \\
\text { - bur-like fruits transported by animal fur }\end{array}$ \\
\hline Phenology & - drought-deciduous loses leaves in May & - winter-deciduous & - drought-deciduous \\
\hline Associations & $\begin{array}{l}\text { - seedlings often associated with white } \\
\text { bursage }\end{array}$ & none known & $\begin{array}{l}\text { - good colonizer species; } \\
\text { "nurse plant" to littleleaf palo verde } \\
\text { and creosotebush seedlings }\end{array}$ \\
\hline $\begin{array}{l}\text { Seasonal } \\
\text { vulnerability to } \\
\text { browsing }\end{array}$ & $\begin{array}{l}\text { spring-but browsed most heavily by } \\
\text { burros from July-Nov. }\end{array}$ & $\begin{array}{l}\text { early summer-but browsed most } \\
\text { heavily by burros Oct.-Jan. }\end{array}$ & $\begin{array}{l}\text { fall-when leaves are maturing; burros } \\
\text { prefer from Dec.-Jan. }\end{array}$ \\
\hline $\begin{array}{l}\text { Palatability to } \\
\text { browsers }\end{array}$ & $\begin{array}{l}\text { fruits only eaten when all other } \\
\text { food gone; browsed by burros. } \\
\text { hares, livestock }\end{array}$ & $\begin{array}{l}\text { browsed throughout year; } \\
\text { browsed by burros, livestock } \\
\text { and other native herbivores }\end{array}$ & $\begin{array}{l}\text { browsed by burros and hares, } \\
\text { and other native herbivores }\end{array}$ \\
\hline $\begin{array}{l}\text { Potential risk } \\
\text { over-browsing }\end{array}$ & MODERATE & LOW & $\mathrm{HIGH}$ \\
\hline
\end{tabular}


able to assume that the degree to which the three species are at risk of impact by burros is an inter-related function of individual plant characters, the degree and timing of stocking rates, and variable climate factors such as drought.

Therefore, in a simplified sense, the ecological risk associated with grazing for these perennial plants is primarily related to their capacity to recover both individually and within their communities. For ecosystem processes to function adequately and for the basic community composition to be preserved, all species must recover concurrently and no one species must be significantly more impacted than another.

A synthesis of available information that describes the life history and morphological characters of the three shrub species, their interspecies associations, and the predominant landscape vegetation types that they comprise, provided a relative assignment of ecological risks for the species. In particular, white bursage is the species at highest risk from over-browsing by burros in Lake Mead National Recreation Area and therefore, the species is an effective indicator of health of the vegetation system in which it occurs.

About the authors: Bonham is retired from the Rangeland Ecosystem Science Department and Brown is with the Cooperative Extension Service through Colorado State University, Ft. Collins, CO 80523

\section{References}

Bailey, R. G. 1998. Ecoregions: the ecosystem geography of the oceans and continents. Springer-Verlag, New York. 192p.

Blydenstein, J., R. R. Humphrey, C. R. Hungerford, and G. I. Day. 1957. Effects of domestic livestock exclusion on vegetation of the Sonoran desert. Ecology 38: 522-526.

Brown, D. E. and C. H. Lowe. 1980. Biotic communities of the southwest. USDA-FS Gen. Tech. Rpt. RM-78. RMFRES, USDA-FS, Ft. Collins.

Calabrese, E. J., and L. A. Baldwin. 1993. Performing Ecological Risk Assessments. Lewis Publishers, Boca Raton. 257p.

Chambers, J. C. and B. E. Norton. 1993. Effects of grazing and drought on population dynamics of salt desert shrub species on the Desert Experimental Range, Utah. Jour. of Arid Environ. 24: $261-275$.

Goldberg, D. E. and R. M. Turner. 1986. Vegetation change and plant demography in permanent plots in the Sonoran Desert. Ecology 67: 695-712.

Hanley, T. A. and W. W. Brady. 1977. Feral burro impact on a Sonoran Desert range. J. Range Manage. 30: 374-377.

Holechek, J. L. 1991. Chihuahuan desert rangeland, livestock grazing, and sustainability. Rangelands 13: 115-120.

Leake, D. V., J. B. Leake, and M. L. Roeder. 1993. Desert and Mountain Plants of the Southwest. Univ. Oklahoma Press, Norman. 239p.
McAulliffe, J. R. 1986. Herbivore-limited establishment of a Sonoran desert tree, Cercidium microphyllum. Ecology 67:276280 .

National Research Council. 1993. Issues in Risk Assessment. National Academy Press. Washington. 356p.

Ramirez, R. G., J. G. Sauceda, J. A. Narro, and J. Aranda. 1993. Preference indices for forage species grazed by Spanish goats on a semiarid shrub land in Mexico. J. Applied Animal Res 3: 55-66.

Roundy B. A. and A. K. Dobrenz. 1989. Herbivory and plant water status of jojoba [Simmondsia chinensis (Link) Schn.] in the Sonoran Desert in Arizona. J. Arid Environ. 16: 283-291.

Schultze E. D. and J. R. Ehleringer, 1984. The effect of nitrogen supply on growth and water-use efficiency of xylem-tapping mistletoes. Planta 162: 268-275.

Suter, G. W. 1993. Ecological Risk Assessment. Lewis Publishers, Boca Raton. 538p.

Turner, R. M. 1982. Mojave desert scrub biome. In: D. E. Brown (Ed.), Desert Plants: Biotic communities of the American Southwest-United States and Mexico 4:156-168. Univ. Arizona Press, Tucson. 342p.

Turner, R. M.. 1990. Long-term vegetation change at a fully protected Sonoran desert site. Ecology 71: 464-477.

USEPA. 1993. A review of ecological assessment case studies from a risk assessment perspective. EPA/630/R-92/005. Washington, D. C. 439 p.

Woodward, S. L. and R. D. Ohmart. 1976. Habitat use and fecal analysis of feral burros (Equus asinus), Chemehuevi Mountains, California. J. Range Manage. 29: 482-485. 